Krzysztof Kozłowski

\title{
Wybrane konstytucyjnoprawne aspekty praw wyborczych obywateli UE niebędących obywatelami polskimi
}

\author{
Selected constitutional aspects of electoral rights of EU citizens \\ who do not possess Polish citizenship
}

\begin{abstract}
The study concerns the relations between the Polish Constitution of 1997 and the regulations of EU treaties in the area of granting EU citizens who are not Polish citizens electoral rights on the territory of the Polish state. These rights refer to active and passive electoral law with regard to elections to the European Parliament and to local self-government (commune). Electoral rights are treated as an institution intended only for Polish citizens. Thus there is a situation of incompatibility between the constitutional standard and the electoral rights of all EU citizens. This problem has been considered by the Polish Constitutional Tribunal, but due to its complexity and its systemic nature has not been resolved.
\end{abstract}

Keywords: Constitution, Polish citizenship, EU citizenship, European Parliament

Opracowanie dotyczy relacji między polską Konstytucją z 1997 r. a przepisami traktatów UE w zakresie przyznawania obywatelom Unii Europejskiej niebędącym obywatelami polskimi praw wyborczych na terytorium państwa polskiego. Prawa te odnoszą się do czynnego i biernego prawa wyborczego mającego zastosowanie w wyborach do Parlamentu Europejskiego i do samorządu lokalnego (gminy). Prawa wyborcze do organów władzy publicznej, w świetle polskiej ustawy zasadniczej, traktowane są jako instytucja przeznaczona wyłącznie dla obywateli polskich. Istnieje zatem stan niezgodności między standardem konstytucyjnym a zagwarantowaniem praw wyborczych wszystkim obywatelom UE. Problem ten był rozpatrywany przez polski Trybunał Konstytucyjny, ale ze względu na jego złożoność i systemową naturę nie został rozwiązany.

Słowa kluczowe: Konstytucja, obywatelstwo polskie, obywatelstwo UE, Parlament Europejski

Doktor nauk prawnych, adiunkt -

Uniwersytet Jagielloński, Wydział Prawa i Administracji, Katedra Prawa Konstytucyjnego,

KRAKÓW, POLSKA .

krzys.kozlowski@uj.edu.pl • https://orcid.org/0000-0002-7439-7165

\section{Wstęp}

Europejski projekt integracyjny został pomyślany jako inicjatywa mająca przede wszystkim wymiar gospodarczy, aby z biegiem czasu nabrać również cech charakterystycznych dla mechanizmu politycznego. W tej sferze wprowadzono m.in. instytucję obywatelstwa unijnego, z którą powiązano wiele praw i obowiązków, które odtąd miały być wykonywanie nie tylko na poziomie wspólnoty, ale również bezpośrednio we wszystkich państwach członkowskich. Chyba najbardziej znaczącym przykładem tej ostatniej kategorii praw jest umocowanie obywateli Unii Europejskiej do udziału w procesie elekcyjnym. Dotyczy to wyborów do 
Parlamentu Europejskiego oraz do lokalnego samorządu terytorialnego w poszczególnych państwach członkowskich, a samo uprawnienie jest przez nich realizowane bez względu na fakt posiadania obywatelstwa narodowego kraju, w którym z tych mechanizmów korzystają. W polskich warunkach oznacza to, że cudzoziemcy, legitymujący się unijnym obywatelstwem, mogą korzystać z czynnego i biernego prawa wyborczego w toku elekcji z terytorium Rzeczypospolitej posłów do $\mathrm{PE}$, jak również cieszą się z pełnego prawa wybierania i (jedynie zakresowo ujętego) prawa wybieralności do organów sprawujących władzę w gminie.

Przywołane kwestie, jakkolwiek realizują szczytne idee integracji europejskiej, którym aksjologicznych podstaw oraz prawnej racjonalności odmówić nie można, to jednak mogą wywoływać zasadnicze wątpliwości natury konstytucyjnej. Wynika to przede wszystkim z istotnej ustrojowo i jednocześnie fundamentalnej dla konstytucyjnego porządku prawnego reguły suwerenności narodu polskiego, dla którego ustawa zasadnicza potwierdza wyłączne prawo do sprawowania władzy zwierzchniej w Rzeczypospolitej. Władza przyznana samorządowi terytorialnemu nie jest przy tym kategorialnie inna od jurysdykcji sprawowanej przez organy władzy państwowej, nie ma zatem podstaw, aby przydawać ją niepolskim obywatelom UE. Podobnie rzecz ma się z wyborami do PE, który przecież nie sprawuje jakiejś wyabstrahowanej władzy ponad państwami narodowymi, a jedynie wykonuje ten zakres uprawnień publicznych, które pierwotnie były udziałem państw członkowskich i na mocy traktatów zostały mu delegowane. Taki też jest zakres władzy udzielonej europejskim deputowanym, co uzasadnia powiązanie ich wyboru ze sferą indywidualnej suwerenności państw członkowskich. Wskazane kwestie zdają się również istotnie ingerować w istotę instytucji obywatelstwa polskiego, które cały czas słusznie powiązane jest z uprzywilejowaniem osób złączonych z Rzeczpospolitą tym szczególnym węzłem publicznoprawnym, jakim jest obywatelstwo. Nie chodzi tu jednak wyłącznie o jego merytoryczną konstrukcję, ale - co nie mniej ważne - powiązane jest z nakazem wierności Rzeczypospolitej oraz niezbędnością troski o dobro wspólne, którymi to powinnościami nie są związani inny obywatele UE. Nie bez powodu Konstytucja z 1997 r. przydaje tylko obywatelom polskim wyłączne prawo do sprawowania władzy publicznej, co, na gruncie jej postanowień, nie jest już jednak adresowane do żadnej innej kategorii osób, w tym nawet do cudzoziemców będących obywatelami UE. Problem konstytucyjny jest zatem doniosły, mający zresztą już swoją historię prawną i polityczną, a przez to obrosły w ustalenia dogmatyczne i jurydyczne, choć cały czas jednak nie do końca rozwiązany.

Niniejsze opracowanie jest jedynie głosem w toczącej się dyskusji, formułowanym ze ściśle dogmatycznego punktu widzenia. Wychodzi ono naprzeciwko tezie o możliwej niekonstytucyjności przydania praw wyborczych obywatelom UE, niebędącym obywatelami polskimi, w sytuacji gdy ustawa zasadnicza odczytywana będzie w sposób dość zachowawczy i pozostający jednak w paradygmacie (ściśle) językowego pojmowania jej przepisów, przy jednoczesnym po- 
ważnym dostrzeżeniu argumentów natury systemowej. Przeprowadzona analiza została sformułowana ze świadomością, że podniesione w jej treści kwestie były już co do zasady przedmiotem aprobujących rozstrzygnięć polskiego Trybunału Konstytucyjnego. Niemniej, jak się wydaje, pewne wątpliwości nadal mogą być zgłaszane i tej kwestii, co do istoty, służą zaprezentowane w niniejszym artykule rozważania.

\section{Prawa wyborcze w świetle art. 4 i art. 62 ust. 1 Konstytucji}

W naukach prawnych podaje się pewne cechy szczególne aktu konstytucyjnego, które pozwalają na jego wyróżnienie spośród innych części systemu źródeł prawa, jak również ukazania jego roli w życiu społecznym czy gospodarczym ${ }^{1}$. Najczęściej przywoływanymi elementami składowymi takiej definicji jest określenie ustroju państwa, przesądzenie o kształcie organów władzy publicznej i zachodzących między nimi relacji oraz przywołanie określonych praw, wolności i obowiązków człowieka i obywatela, a także uściślenie stosunków między tymi ostatnimi a organami władzy publicznej ${ }^{2}$. Kolejną cechą szczególną takich rozwiązań - wydaje się, że o znaczeniu kluczowym - jest wskazanie suwerena i jego roli w systemie ustrojowym państwa, co nabiera szczególnego znaczenia w dobie silnych procesów globalizacyjnych i integracyjnych ${ }^{3}$. Od tego modelowego ujęcia nie odbiega obowiązująca Konstytucja RP z 1997 r. ${ }^{4}$. W swojej treści projektuje ona te wszystkie zagadnienia, które konstytucjonalizm adresuje do aktu prawnego o najwyższej mocy obowiązującej ${ }^{5}$. Obserwacja ta ma również zastosowanie do wskazania podmiotu, który sprawuje władzę suwerenną w państwie polskim. Przesądzenie tej kwestii znalazło swoje miejsce już w postanowieniach preambuły, gdzie przywołuje się „Naród Polski”, a nadto wskazuje na jego zdolność do „ustanowienia Konstytucji Rzeczypospolitej Polskiej jako prawa podstawowego dla państwa”. Dalsze, już zasadnicze regulacje konstytucyjne, zdają się tę regułę jeszcze bardziej potwierdzać - sugestywne jest w tej mierze obowiązy-

1 Szerzej I. Małajny, Konstytucja - rodzaje i koncepcje, „Gdańskie Studia Prawnicze” 2014, t. 31, s. 637-645.

2 O różnorodności definicyjnej R. Małajny, Pojęcie konstytucji, „Państwo i Prawo” 2018, z. 2, s. 3-21.

3 Szeroką analizę zagadnienia suwerenności przedstawia J. Ciapała, Wokół pojmowania $i$ wykonywania suwerenności w warunkach członkostwa $w$ Unii Europejskiej - kilka uwag podstawowych, lecz czy przekonujących?, „Gdańskie Studia Prawnicze” 2014, t. 31 , s. 85-87.

$4 \quad$ Konstytucja Rzeczypospolitej Polskiej z 2 kwietnia 1997 r., Dz.U. nr 78, poz. 483, ze zm.; dalej: Konstytucja.

$5 \quad$ Analitycznie o tym zagadnieniu P. Tuleja, Stosowanie Konstytucji RP w świetle zasady jej nadrzędności, Kraków 2003, s. 63-97. 
wanie art. 4 ust. 1 Konstytucji, który stwierdza, że: „Władza zwierzchnia w Rzeczypospolitej Polskiej należy do Narodu”. Wymowa tego przepisu jest niezwykle istotna, albowiem wskazuje on piastuna władzy najwyższej w państwie polskim, a więc przesądza o tym, jaki podmiot jest suwerenem. $Z$ tą ostatnią funkcją ustawa zasadnicza wiąże sprawowanie całokształtu władzy publicznej, „przez swoich przedstawicieli lub bezpośrednio” (art. 4 ust. 2 Konstytucji). Również i w tym przepisie następuje wskazanie na „Naród” jako ten, który obdarzony jest kwalifikowanym przymiotem w systemie ustrojowym państwa ${ }^{6}$. Desygnacja ta nie budzi również wątpliwości w sferze wyłączności „Narodu Polskiego” do wykonywania najwyższego mandatu publicznego, co oznacza, że żaden inny podmiot nie ma w Polsce tak szerokiej i jednocześnie zwierzchniej władzy ${ }^{7}$. Inne podejście bardzo trudno byłoby też pogodzić z nakazem strzeżenia niepodległości (art. 5 Konstytucji). Koniecznym zaś jej elementem zdaje się być polityczna niezależność, której korelatem jest zdolność organizacji państwowej do samodzielnego oraz bezwpływowego rozstrzygania o całokształcie (wewnętrznych i zewnętrznych) spraw publicznych, czemu oczywiście nie należy przeciwstawiać reguły otwartości na współpracę międzynarodową (art. 9 Konstytucji).

$\mathrm{Na}$ tle poczynionych rozważań pozostaje jednak konieczność zdefiniowania kategorii podmiotów, które mieszczą się w zakresie pojęcia „Narodu Polskiego”. Rozważania dogmatyczne zazwyczaj odwołują się do tego zwrotu w trojakim jego znaczeniu, a mianowicie politycznym, etnicznym lub społecznym ${ }^{8}$, choć „nie ulega wątpliwości, że ustrojodawca posługuje się pojęciem «Naród» w znaczeniu politycznym, nie zaś etnicznym". Tak skonstruowany podział znajduje zresztą swoje bardzo silne umocowanie w systemowej oraz funkcjonalnej analizie unormowań ustawy zasadniczej. Można w tej sferze jeszcze raz przywołać postanowienia preambuły, która w sposób przesądzający stawia znak równości między „Narodem Polskim” a konglomeratem „wszystkich obywateli Rzeczypospolitej”, co pozostaje w obszarze pewnej jednorodności znaczeniowej. Potwierdza to odnośne orzecznictwo konstytucyjne, stwierdzając, że „pojęcie Naród określa wspólnotę, którą tworzą obywatele Rzeczypospolitej” ${ }^{10}$. Kategorię tę należy zaś odróżnić od polonijnie wybrzmiewającego zwrotu „złączonych więzami wspólnoty naszych rodaków rozsianych po świecie”. Dalsze regulacje konstytucyjne również utrzymują tak zakreślone rozróżnienie. Istotny będzie tu przykład, w którym ustrojodawca wyraźnie przywołuje kategorię „obywateli”,

6 A. Szmyt, Normatywny wyraz idei demokracji przedstawicielskiej i bezpośredniej w Konstytucji RP z 1997 roku, „Gdańskie Studia Prawnicze” 2009, nr 1, s. 302.

7 Ibidem, s. 303-304.

8 D. Harasimiuk, Obywatelstwo UE - element tożsamości narodowej, europejskiej, czy jedynie dodatkowy status obywateli państw członkowskich?, „Ius Novum” 2017, nr 3, s. 124.

$9 \quad$ A. Szmyt, Normatywny wyraz, op. cit., s. 304.

10 Wyrok TK z 31 maja 2004 r., sygn. akt K 15/04, OTK-A ZU 2004, nr 5, poz. 47. 
nakazując w szczególności zapewnienie im bezpieczeństwa (art. 5 Konstytucji) i rozgranicza adresowane do nich uprawnienia od tego, co przynależy się „Polakom zamieszkałym zagranicą” m.in. w sferze „zachowania związków z narodowym dziedzictwem kulturalnym” (art. 6 ust. 2 Konstytucji). Ustawa zasadnicza indywidualizuje zatem pojęcia „obywatela” i pozostałych uczestników obrotu prawnego, przypisując im prawnie określoną i zarazem heterogeniczną pozycję w systemie ustrojowym państwa polskiego ${ }^{11}$. Znajduje to zresztą swoje odzwierciedlenie w tych postanowieniach Konstytucji, które kategoryzują określone prawa, wolności i obowiązki w zależności od tego, czy ich adresatem jest „obywatel polski” (np. art. 60 Konstytucji), „Polak” (art. 6 ust. 2 Konstytucji), „cudzoziemiec” (art. 56 Konstytucji) oraz „każdy” człowiek (np. art. 47 Konstytucji).

W wyżej przywołanym ujęciu ustawa zasadnicza wręcz paradygmatycznie posługuje się kategorią „Narodu” jako zbiorowości „wszystkich obywateli” i tylko tym osobom, na zasadzie wyłączności, powierza sprawowanie „władzy zwierzchniej” w Rzeczypospolitej Polskiej, a zatem buduje instytucję suwerena tylko z tak zakwalifikowanych jednostek (art. 4 Konstytucji) ${ }^{12}$. Nie może zatem dziwić, że w konsekwencji wyłącznie obywatelom polskim ustrojodawca przyznał czynne prawo wyborcze, zarówno do organów władzy państwowej („prawo wybierania Prezydenta Rzeczypospolitej, posłów, senatorów”), jak również do „organów samorządu terytorialnego", o ile ukończą 18 lat najpóźniej w dniu głosowania (art. 62 ust. 1 Konstytucji). Zależność między wskazaniem suwerena złożonego z konglomeratu obywateli (art. 4 Konstytucji) a wyłącznym powierzeniem im czynnego prawa wyborczego do organów władzy publicznej (art. 62 ust. 1 Konstytucji) jawi się wręcz jako oczywista. Równoległa obserwacja odnosi się zresztą do biernego prawa wyborczego (art. 99 ust. 1 i 2 i art. 127 ust. 3 Konstytucji). Co więcej, kwestia zastrzeżenia wyłącznie dla obywateli praw elekcyjnych powinna być wiązana $\mathrm{z}$ samą istotą instytucji obywatelstwa w państwie o ustroju republikańskim. W doktrynie podkreśla się, że obywatelstwo jest więzią szczególną, kwalifikowaną prawnie i zarazem ekskluzywną, a także przydającą taki zakres praw, wolności i obowiązków, które nie są lub nie mogą (np. ze względów bezpieczeństwa - art. 85 Konstytucji) być zaadresowane do innych jednostek ${ }^{13}$. Ustrojowa cecha republikanizmu nakazuje przyznać obywatelom wyłączne prawo rządzenia, jako korelatu ich odpowiedzialności za państwo i funkcjonalnie

11 Wartościową analizę relacji pomiędzy instytucją obywatelstwa UE a realizacją uprawnień wyborczych i życia politycznego w państwach członkowskich przedstawia S. Konopacki, Dylematy obywatelstwa europejskiego, „Studia Europejskie” 2003, nr 4, s. 6672, i przywołana tam literatura.

12 Szerzej A. Szmyt, Normatywny wyraz, op. cit., s. 302-304.

13 Pozycję prawną obywatela wraz z literaturą zagadnienia przedstawia J. Adamczyk, Pojęcie i znaczenie obywatelstwa, „Studia Prawnicze i Administracyjne” 2018, nr 3, s. 3-5, 8-9. 
powiązaną z nim wspólnotę wszystkich pozostałych obywateli ${ }^{14}$. Nie bez powodu ustawa zasadnicza nakłada tylko na obywateli polskich obowiązek „wierności Rzeczypospolitej” oraz „troski o dobro wspólne” (art. 82 Konstytucji), również w tak głębokim charakterze, jaki związany jest z zadysponowaniem własną osobą w wykonaniu obowiązku jej obrony (art. 85 ust. 1 i 2 Konstytucji), co może mieć miejsce w sytuacji naruszenia ustrojowych fundamentów funkcjonowania państwa (art. 5 w związku z art. 26 Konstytucji). To wszystko zaś złączone jest perspektywą ujęcia instytucji obywatelstwa, jako mechanizmu realizującego postulat funkcjonowania państwa polskiego w kategoriach „dobra wspólnego wszystkich obywateli” (art. 1 Konstytucji). Ustawa zasadnicza buduje pojęcie suwerena, umocowanego do sprawowania władzy publicznej w Polsce, wyłącznie z obywateli, co czyni nie tylko ze względu na samą dogmatyczną konstrukcję państwa demokratycznego (władza obywatelskiego demos - art. 2 Konstytucji), ale również realizuje to ze względu na republikański ustrój państwa oraz regułę pluralizmu politycznego (art. 11 Konstytucji) ${ }^{15}$, a przez to silnie służebne zobowiązanie obywateli do wierności oraz troski o dobro wspólne (art. 1 Konstytucji), czego współczesnym oczywistym przejawem jest wykonywanie praw wyborczych (art. 62 ust. 1 Konstytucji). Tym samym wyłącznie osoby objęte węzłem obywatelstwa, sprawujący władzę publiczną w Rzeczypospolitej, korzystają ze szczególnego umocowania i zarazem predestynacji do wykonywania uprawnień elekcyjnych ${ }^{16}$.

\section{Prawa wyborcze obywateli UE niebędącymi obywatelami polskimi w wyborach do Parlamentu Europejskiego}

Projekt europejski, który dekadę po zakończeniu II wojny światowej zaowocował powstaniem Wspólnot Europejskich, był początkowo pomyślany jako porozumienie gospodarcze. $Z$ biegiem czasu nadano mu jednak również silny walor instytucjonalny i polityczny ${ }^{17}$. W ślad za tym nastąpiło zeuropeizowanie pozycji prawnej obywateli państw członkowskich, którego uwieńczeniem było powstanie europejskiego obywatelstwa ${ }^{18}$. Powiązano z nim liczne prawa (i obowiązki) egzekwowalne na poziomie unijnym, w tym również uprawnienia polityczne, które do tej pory funkcjonowały w sferze państw narodowych. Jednym z nich

14 Część doktryny zdaje się rekomendować odejście od tego paradygmatu - dla przykładu A. Piekutowska, Prawa wyborcze imigrantów. Refleksje na tle instytucji obywatelstwa europejskiego, „Białostockie Studia Prawnicze” 2016, t. 20, s. 183-189.

15 A. Szmyt, Normatywny wyraz, op. cit., s. 303.

16 Odmiennie, z krytycznym przywołaniem „starożytnej koncepcji cenzusu obywatelskiego" A. Piekutowska, Prawa, op. cit., s. 185.

17 D. Harasimiuk, Obywatelstwo, op. cit., s. 122.

18 Szerzej S. Konopacki, Dylematy, op. cit., s. 53-54, i przywołana tam literatura. 
jest traktatowe ${ }^{19}$ prawo do udziału w wyborach do Parlamentu Europejskiego. W art. 22 ust. 2 zdanie 1 TFUE stwierdza się, że „[...] każdy obywatel Unii mający miejsce zamieszkania w Państwie Członkowskim, którego nie jest obywatelem, ma prawo głosowania i kandydowania w wyborach do Parlamentu Europejskiego w Państwie Członkowskim, w którym ma miejsce zamieszkania, na takich samych zasadach jak obywatele tego państwa”. Traktat ustanawia zatem regułę równorzędności pomiędzy wszystkimi obywatelami UE w sferze możliwości realizacji prawa wybierania i wybieralności do PE. Konstytuują je zasadniczo trzy elementy, tj. posiadanie obywatelstwa UE, domicyl oraz zasada niedyskrymina$\mathrm{cji}^{20}$. Reguły te znajdują zresztą swoje odzwierciedlenie w decyzji odesłanej na mocy art. 22 ust. 2 zdanie drugie TFUE ${ }^{21}$ oraz dyrektywie dedykowanej temu zagadnieniu $^{22}$, jak również europejskiej ogólnej regulacji ordynacyjnej ${ }^{23}$. Przywołane regulacje ustanawiają prawo polityczne o charakterze elekcyjnym, zaadresowane do wszystkich obywateli UE, którego treścią jest możliwość realizacji czynnego i biernego prawa wyborczego w wyborach do PE w kraju faktycznego ich zamieszkiwana i to bez względu na fakt posiadania obywatelstwa tego państwa $^{24}$. Mamy zatem do czynienia ze swoistym „odmiejscowieniem” praw elekcyjnych, a przez to odejściem od tradycyjnej formuły, na mocy której przypisywane są one wyłącznie obywatelom państwa, w którym mają być wykonywane.

Podstawowy problem konstytucyjny, jaki rysuje się na tle powyższych unormowań, dotyczy tego, czy osoby, które nie mają obywatelstwa polskiego, mogą wykonywać na terytorium Rzeczypospolitej, na równi z polskimi obywatelami, to szczególne prawo polityczne, jakim jest zdolność elekcyjna (czynna i bierna) w wyborach do PE. Trzeba tu jednak od razu zaznaczyć, że w tym wypadku nie znajdzie zastosowania art. 62 ust. 1 Konstytucji. Przepis ten reguluje bowiem wyłącznie wykonywanie uprawnień wyborczych, dedykowanych polskim obywate-

19 Traktat o funkcjonowaniu Unii Europejskiej, wersja skonsolidowana, Dz.Urz. UE C 326 z 26 października 2012 r.; dalej: TFUE.

20 Wyrok TSUE z 12 września 2006 r., O.B. Sevinger v. College Van Burgemeester en Wethouders Van Den Haag, sygn. akt C-300/04, LEX nr 226915.

21 Akt dotyczący wyborów członków Parlamentu Europejskiego w powszechnych wyborach bezpośrednich, załączony do decyzji Rady 76/787/EWWiS, EWG, Euratom z 20 września 1976 r., Dz.Urz. UE L 278 z 8 października 1976 r.

22 Dyrektywa Rady 93/109/WE z 6 grudnia 1993 r. ustanawiająca szczegółowe warunki wykonywania prawa głosowania i kandydowania w wyborach do Parlamentu Europejskiego przez obywateli Unii mających miejsce zamieszkania w Państwie Członkowskim, którego nie są obywatelami, Dz.Urz. UE L 329 z 30 grudnia 1993 r.

23 Akt dotyczący wyboru członków Parlamentu Europejskiego w powszechnych wyborach bezpośrednich stanowiący załącznik do decyzji Rady 76/787/EWWiS, EWG, Euroatom, Dz.Urz. UE L 278 z 8 października 1978 r., ze zm.

24 Szerzej M. Rulka, Regulacja wyborów do Parlamentu Europejskiego w prawie Unii Europejskiej, „Studia Wyborcze” 2013, t. 16, s. 35-41. 
lom, ale w odniesieniu do udzielania mandatum piastunom krajowych organów władzy publicznej. Regulacja tworzy bowiem enumeratywny katalog funkcji publicznych, które pochodzą z wyboru obywateli polskich. Zwraca uwagę, że ustawa zasadnicza wylicza $\mathrm{w}$ tym unormowaniu konstytucyjne organy państwa o charakterze rządowym oraz samorządowym, w żadnej mierze nie przywołując ciał statutowych organizacji międzynarodowych. Można wręcz zauważyć, że przepis ten ukierunkowany jest do wewnątrz konstytucyjnej struktury organów władzy państwa polskiego, a jego jednoznaczna literalnie treść wyklucza jakąkolwiek ekstensywną wykładnię. Podobną obserwację należy zaadresować do innych regulacji konstytucyjnych, które normują zakres biernego prawa wyborczego. One także do kwestii wyborów do PE się nie odnoszą. Ustrojodawca dokonuje bardzo wyraźnego, wręcz dychotomicznego, podziału postanowień konstytucyjnych na te, które w wymiarze publicznym regulują krajowe stosunki prawne (np. art. 5, art. 10 Konstytucji), oraz te, które zawierają w sobie pierwiastek prawnomiędzynarodowy (np. art. 9, art. 90 Konstytucji). Bez wątpienia art. 62 ust. 1 Konstytucji nie jest przepisem, który stałby w kolizji z tymi postanowieniami TFUE, które przydają praw elekcyjnych niepolskim obywatelom UE w Polsce. Trudno jest bowiem przy tym założyć jakąś intencję ustrojodawcy, przewidującego „wpływ nieobywateli na wynik wyborów" do krajowych organów władzy publicznej ${ }^{25}$.

Sprawa ulegnie jednak komplikacji, gdy zważy się na równoległe obowiązywanie w tej sferze art. 4 Konstytucji ${ }^{26}$. Był on już omówiony w pierwszej części niniejszego opracowania, a obecnie należy jedynie powtórzyć, że przewiduje on regułę suwerenności narodu polskiego, a zatem wskazuje, że wyłącznie ów naród, konstytucyjnie rozumiany jako konglomerat obywateli polskich, ma wyłączne prawo do sprawowania władzy publicznej w Rzeczypospolitej (art. 4 ust. 1 Konstytucji). Nabiera to zresztą szczególnego ugruntowania (operacjonalizacji) we wskazaniu, że publiczna jurysdykcja może być sprawowana bezpośrednio, a więc z zastosowaniem instrumentów demokracji przedstawicielskiej, do których zaliczamy wybory, jak również przez odpowiednio umocowanych reprezentantów (art. 4 ust. 2 Konstytucji ${ }^{27}$. Pojawia się zatem zagadnienie, czy przydanie obywatelom UE, którzy nie mają polskiego obywatelstwa, uprawnień do korzysta-

25 Podobny problem dostrzega M. Rulka, Współczesne warunki posiadania prawa do głosowania a powszechność wyborów, „Studia Prawnicze i Administracyjne” 2017, nr 1, s. 49.

26 Część doktryny jest krytyczna wobec przywoływania przepisów konstytucyjnych przy analizie wyborów do PE ze względu na obserwację, że „jak wiadomo, Konstytucja Rzeczypospolitej nie zawiera jeszcze żadnych odniesień do członkostwa Polski w Unii Europejskiej, stąd też trudno byłoby postulować, aby konstytucjonalizacji podlegała ta szczególna sprawa, jaką jest wybór członków PE”, gdyż jest to „procedura pozakonstytucyjna", o czym przekonuje P. Sarnecki, Regulacje ustawowe dotyczące wyborów na terenie Rzeczypospolitej Polskiej posłów do Parlamentu Europejskiego, „Przegląd Sejmowy" 2004, nr 3, s. 12, 14.

27 Szerzej A. Szmyt, Normatywny wyraz, op. cit., s. 302-304. 
nia w Polsce z uprawnień elekcyjnych - czynnych i biernych - w toku europejskiej procedury wyborczej, stoi w jakiejś kolizji z regułą suwerenności narodu polskiego. W syntetycznym ujęciu jest to pytanie o „konieczność dopuszczenia do głosowania i kandydowania obywateli innych państw UE bez podstawy konstytucyjnej”28. Część doktryny udziela na nie dość kategorycznej odpowiedzi, wskazując, że problem ten „jest zasadniczo bezprzedmiotowy”, a „instytucja Parlamentu Europejskiego nie jest [...] instytucją Konstytucji RP jako państwa, lecz odrębnego, samodzielnego porządku prawnego" ${ }^{29}$. Takie też stanowisko zajął nasz Trybunał Konstytucyjny ${ }^{30}$. Niemniej należy rozważyć, jaka jest relacja między pojęciem „władzy zwierzchniej” przynależnej w państwie polskim do narodu (art. 4 ust. 1 Konstytucji), a źródłami i zakresem władzy wykonywanej przez Parlament Europejski w ramach funkcjonowania UE, co tym samym rozstrzyga o treści legitymacji publicznej, która jest przydana europejskim deputowanym.

Należy wskazać, że charakter prawny samej UE zdeterminowany jest unormowaniami prawa międzynarodowego, w szczególności konwencji wiedeńskiej o prawie traktatów ${ }^{31}$. W jej świetle Unia pozostaje jedną z wielu organizacji międzynarodowych, której ustanawianie, funkcjonowanie oraz rozwiązywanie podlega ogólnym regułom tego prawa, a które jest dla Polski wiążące (art. 9 Konstytucji w związku z art. 26 KWPT). Tworzona jest ona przez państwa strony traktatów (art. 5 w związku z art. 9 ust. 1 KWPT) i na podstawie ich decyzji może utracić swój byt prawny (art. 42 ust. 2 w związku z art. 56 KWPT). Tym samym nie ma ona autonomicznej (samodzielnej) pozycji ustrojowej względem konstytuujących ją państw członkowskich. Powinna być zatem charakteryzowana jako podmiot wtórny wobec poszczególnych państw narodowych i w pełni uzależniony od ich prawonokształtującej woli, czego dowodzi postępowanie brexitowe, a co również przewidziane zostało w art. 50 Traktatu o Unii Europejskiej $^{32}$, jako powtórzenie kanonu wynikającego z art. $54 \mathrm{KWPT}^{33}$. Reguły prawa międzynarodowego determinują również zakres jurysdykcji, którą UE może sprawować względem państw członkowskich, a tym samym przesądzają o kształcie władztwa, które przysługuje PE, jako jednemu z organów samej Unii. Potwierdza to zresztą Traktat o Unii Europejskiej, w którym ten mechanizm

28 P. Sarnecki, Regulacje, op. cit., s. 12.

${ }^{29}$ K. Działocha, Zgodność zmian w prawie wyborczym z Konstytucja RP (w związku z przystapieniem Polski do Unii Europejskiej), „Państwo i Prawo” 2003, z. 11, s. 14.

30 Wyrok TK z 31 maja 2004 r., sygn. akt K 15/04.

31 Konwencja wiedeńska o prawie traktatów sporządzona w Wiedniu 23 maja 1969 r., Dz.U. 1990, nr 74, poz. 439; dalej: KWPT.

32 Traktat o Unii Europejskiej, wersja skonsolidowana, Dz.Urz. UE C 326 z 26 października 2012 r.; dalej: TUE. Szerzej na ten temat I. Parchimowicz, Prawo do wystapienia z Unii Europejskiej na przykładzie Brexitu, „Europejski Przegląd Sądowy” 2017, nr 9, s. 18-27.

33 Szerzej J. Ciapała, Wokót pojmowania, op. cit., s. 89. 
jest de iure opisany. Przesądza się w nim, że „niniejszym Traktatem Wysokie Umawiające się Strony ustanawiają między sobą Unię Europejską, zwaną dalej «Unią», której Państwa Członkowskie przyznają kompetencje do osiągnięcia ich wspólnych celów" (art. 1 zdanie 1 TUE). Z kolei art. 5 TUE, w zakresie unijnych kompetencji, w sposób precyzyjny przewiduje, że "granice kompetencji Unii wyznacza zasada przyznania. Wykonywanie tych kompetencji podlega zasadom pomocniczości i proporcjonalności” (ust. 1), zaś „zgodnie z zasadą przyznania Unia działa wyłącznie w granicach kompetencji przyznanych jej przez Państwa Członkowskie w Traktatach do osiągnięcia określonych w nich celów. Wszelkie kompetencje nieprzyznane Unii w Traktatach należą do Państw Członkowskich" $\left(\right.$ ust. 2) ${ }^{34}$.W sposób niebudzący wątpliwości przywołane regulacje przypominają wtórny względem państw członkowskich charakter prawny UE, w tym również definiują regułę kompetencji przyznanych. Ujęcie to determinuje również zakres jurysdykcji wykonywanej przez organy samej Unii. Właściwe w tym względzie przepisy traktatowe stwierdzają, że „Unia dysponuje ramami instytucjonalnymi [...]", a „każda instytucja działa w granicach uprawnień przyznanych jej na mocy Traktatów, zgodnie z procedurami, na warunkach i w celach w nich określonych" (art. 13 ust. 1 i 2 TUE). Dotyczy to także Parlamentu Europejskiego, który „[...] pełni, wspólnie z Radą, funkcje prawodawczą i budżetową. Pełni funkcje kontroli politycznej i konsultacyjne" i to tylko ,zgodnie z warunkami przewidzianymi w Traktatach [...]" (art. 14 ust. 1 TUE). Przywołane regulacje określają charakter prawny UE jako organizacji międzynarodowej, która może wykonywać wyłącznie te kompetencje, które w sposób wyraźny zostały jej przyznane na mocy traktatów i tylko w zakresie przez nie określonym. W konsekwencji dotyczy to również zakresu uprawnień, jakie przewidziane są dla jurysdykcji Parlamentu Europejskiego, którego umocowanie także oparte jest na określonych i ściśle limitowanych postanowieniach traktatowych. Wyznaczają one również zakres mandatu powierzanego posłom do PE przez wyborców narodowych ${ }^{35}$.

Przystąpienie Polski do UE na gruncie ustawy zasadniczej skutkowało nie tylko formalnym rezultatem naszej akcesji, a więc prawnym uznaniem członkostwa (przynależności) Rzeczypospolitej w organizacji międzynarodowej (art. 5 KWPT). Decyzja ta miała dużo szerszy skutek, wiązała się bowiem z przekazaniem tej organizacji „kompetencji organów władzy państwowej w niektórych sprawach" (art. 90 ust. 1 Konstytucji) ${ }^{36}$. Tym samym na mocy decyzji

34 Wieloaspektowość kompetencji UE analizuje J. Ciapała, Wokół pojmowania, op. cit., s. 91-93.

35 Częściowo odmiennie J. Szymanek, Stosunek przedstawicielski na poziomie Unii Europejskiej (próba opisu charakteru mandatu), „Przegląd Sejmowy” 2011, nr 3, s. 96-97, 99-102, 106-107.

36 Chyba najgłębsza analiza tego zagadnienia została przeprowadzona w publikacji K. Wojtyczek, Przekazywanie kompetencji państwa organizacjom międzynarodowym. Wybrane zagadnienia prawnokonstytucyjne, Kraków 2007, passim. 
akcesyjnej państwo polskie, stosując kwalifikowaną procedurę konstytucyjną, zdecydowało o przeniesieniu na poziom międzynarodowy części władztwa publicznego. Uczyniło to zaś dla „lepszej realizacji norm materialnoprawnych naszej ustawy zasadniczej" ${ }^{37}$, a nie po to, aby dokonać jej prawnego - nawet dorozumianego (konkludentnego) - unicestwienia. Należy bowiem przyjąć, że „przekazywanie kompetencji jest konstytucyjnie uzasadnione, jeżeli obejmuje kompetencje, których państwo nie jest w stanie skutecznie wykonywać, i prowadzi do sytuacji, w której wartości, cele i zadania państwa są lepiej realizowane poprzez odpowiednie akty prawne Unii Europejskiej"38. Dopełnienie zaś tej czynności we współpracy z UE, na gruncie ustawy zasadniczej, nie jest kategorią funkcjonującą samodzielnie w krajowym systemie prawnym, w tym również nie może być rozpatrywane w oderwaniu od reguły suwerenności narodu i tego jej odwzorowania, które wyraźnie zadekretowano w art. 4 Konstytucji $^{39}$. Decyzja akcesyjna podjęta na mocy art. 90 Konstytucji obejmowała swym zakresem tylko i wyłącznie, bo innych nie mogła, te kompetencje władzy państwowej, które na mocy art. 4 ust. 1 Konstytucji, jako elementy „władzy zwierzchniej” należą do „Narodu Polskiego” i które na poziom unijny zostały wytransferowane przez akt akcesyjny ${ }^{40}$. Unia Europejska nie wykonuje zatem na terytorium Rzeczypospolitej żadnej innej jurysdykcji, niż takiej, która została jej delegowana spośród tego, co pierwotnie przysługiwało polskiemu suwerenowi, a co w traktacie zostało na ten ponadnarodowy poziom przeniesione. Zagadnienie to bardzo mocno dotyka kwestii źródeł legitymacji UE, a te na gruncie polskiej ustawy zasadniczej zdają się być jednoznaczne i oparte na paradygmacie narodowym ${ }^{41}$. To bowiem Rzeczypospolita, a nie UE jako organizacja międzynarodowa, pozostaje nadal suwerenna oraz cieszy się pierwotną atrybucją państwową ${ }^{42}$. Odmienne rozumowanie musiałoby zakładać istnienie jakiejś kategorii unijnych kompetencji, w które organizacja ta została wyposażona poza reżimem traktów, a więc jakichś uprawnień mających charakter abstrakcyjny. Wszystko to, co UE wykonuje, jest przecież bezpośrednio i całkowicie determinowane wolą państw członkowskich, co w odniesieniu do

37 K. Wojtyczek, Wpływ Traktatu z Lizbony na ustrój Polski, „Przegląd Sejmowy” 2010, nr 4, s. 24.

38 Ibidem.

Szerzej G. Kryszeń, K. Prokop, Aksjologia polskiej Konstytucji, Warszawa 2017, s. 7787.

40 Szerzej i częściowo odmiennie J. Ciapała, Wokół pojmowania, op. cit., s. 87-90.

41 Szerzej i częściowo odmiennie C. Mik, Umocnienie legitymacji demokratycznej Unii Europejskiej [w:] Traktat z Lizbony. Główne reformy ustrojowe Unii Europejskiej, red. J. Barcz, Warszawa 2008, s. 100-110.

42 W. Czapliński, Prawo wspólnotowe a prawo wewnętrzne w praktyce sądów konstytucyjnych państw członkowskich (wybrane zagadnienia), „Kwartalnik Prawa Publicznego” 2004, nr 2, s. 9. 
polskiej ustawy zasadniczej nie może odbywać się w sposób wykraczający poza reżim przewidziany w art. 4 Konstytucji.

Pochodzenie uprawnień Parlamentu Europejskiego analogicznie nie wynika z bliżej nieokreślonej jurysdykcji sui generis tego organu, a opiera się na postanowieniach traktatowych i ich przepisami jest ograniczone. Również i w tym wypadku, podobnie jak sama UE, Parlament będący jej organem czerpie swe władztwo wyłącznie z tego, i w zakresie tego, co UE w traktatach zostało przyznane, a to $\mathrm{z}$ kolei determinuje treść mandatum udzielonego europejskim deputowanym ${ }^{43}$. Zakres jego jurysdykcji jest zatem pochodną decyzji akcesyjnej, która odwołuje się do woli wyrażonej w trybie przewidzianym przez art. 90 Konstytucji. Oznacza to, że na forum unijnym sprawuje on taką jurysdykcję, jaką na mocy traktów państwa członkowskie temu organowi przypisały. Na terytorium państwa polskiego wykonuje zaś delegowane władztwo publiczne, jako korelat przekazanego odcinka „władzy zwierzchniej” (art. 4 Konstytucji), a konkretnie „kompetencji [polskich - przyp. K.K.] organów władzy państwowej w niektórych sprawach" (art. 90 ust. 1 Konstytucji). Z kolei sprawowanie tych ostatnich zastrzeżone zostało wyłącznie dla "Narodu Polskiego"44, a więc - co było już przedmiotem analizy - konglomeratu obywateli polskich, a nie jakiejkolwiek innej kategorii osób, choćby na gruncie traktatowym ciszących się unijnym obywatelstwem. Unia może przyznawać swoim obywatelom różnego rodzaju prawa, cieszące się bezpośrednią wykonalnością na poziomie ponadnarodowym, jakimi są przykładowo prawo petycji ${ }^{45}$ lub prawo do opieki dyplomatycznej i konsularnej ${ }^{46}$, ale już, w świetle polskiej ustawy zasadniczej, nie może zagwarantowywać takich uprawnień, które są immanentnie powiązane z suwerennością polskiego narodu i dla jego członków wyłącznie zastrzeżone (art. 4 Konstytucji). Wybór posła do PE jest nie tylko wskazaniem konkretnej osoby do sprawowania mandatum (wymiar indywidualny), ale również ustanowieniem upoważnienia do realizacji władztwa publicznego, które pierwotnie przynależało państwu członkowskiemu i następnie, na zasadach koncesyjnych, zostało delegowane do wykonywania na poziomie unijnym (wymiar kompetencyjny). Nie jest przy tym tak, że na mocy traktatów doszło do jakiegoś „skrzyżowania” się suwerenności poszczególnych państw członkowskich na poziomie PE, jako wyniku bliżej nie-

43 Kwestie definicyjne szeroko analizuje J. Szymanek, Stosunek, op. cit., s. 91-94.

44 Do tej kategorii reprezentacji zdaje się również odwoływać P. Sarnecki, Regulacje, op. cit., s. 13.

45 Szerzej K. Kozłowski, Prawo petycji do Parlamentu Europejskiego jako instrument pozasądowej ochrony praw i wolności [w:] Pozasądowa ochrona praw i wolności jednostki - instytucje, standardy, efektywność, red. E. Wójcicka, Częstochowa 2014, s. 265-274.

46 Szerzej K. Kozłowski, Gwarancja prawa do opieki dyplomatycznej i konsularnej jako element instytucji obywatelstwa Unii Europejskiej [w:] Dookoła Wojtek. Ksiega pamiątkowa poświęcona Doktorowi Arturowi Preisnerowi, red. R. Balicki, M. Jabłoński, Wrocław 2018, s. 269-277. 
sprecyzowanej „tendencji do tworzenia jednego «europejskiego elektoratu»" a jedynie do delegowania do wykonywania określonego ich zakresu na międzynarodowej płaszczyźnie. Wyjaśnieniem problemu zdaje się nie być również „przeniesienie kompetencji, [które - dopisek K.K.] skutkuje kreowaniem wspólnoty, której członkowie działają kolektywnie z wzajemną korzyścią"48. Nie nastąpiło tym samym utworzenie samodzielnej i hybrydowej jurysdykcji Parlamentu Europejskiego, jakoby w opozycji do wertykalnego przekazania kompetencji przez państwa członkowskie na mocy traktatów. W tej sferze zbędne jest sięganie po nieczytelne mechanizmy „mieszania” się władztwa publicznego poszczególnych państw członkowskich, gdyż nadal mamy do czynienia ze „wspólnym wykonywaniem przekazanych kompetencji”" ${ }^{49}$. Wydaje się, że wytłumaczeniem problemu nie jest również sięgnięcie po stwierdzenie, że PE „nie jest organem sprawującym władzę w Rzeczypospolitej Polskiej, lecz organem realizującym określone funkcje w strukturze Unii Europejskiej" ${ }^{\prime 50}$. Jest chyba wręcz przeciwnie, gdyż izba europejska podejmuje decyzje, współstanowiąc w procedurze prawodawczej, uchwalając budżet oraz korzystając z kompetencji kreacyjnych, które, również $\mathrm{w}$ ramach reguły pierwszeństwa i bezpośredniego skutku, są wprost stosowane na terytorium państwa polskiego. W tym zakresie władztwo Parlamentu Europejskiego nie jest abstraktem, a mandatum udzielonym przez państwa członkowskie. Posłowie do PE nie wykonują też żadnej innej władzy, niż ta, która została im powierzona raz przez traktaty (to w wymiarze ogólnym), a dwa - w drodze przyznania przez państwa ich pochodzenia na mocy aktu wyborczego (to $\mathrm{w}$ wymiarze indywidualnym $)^{51}$. Przecież, jak do tej pory, również w wymiarze politycznym, większościowo została przyjęta „wizja swego rodzaju «delegacji narodowych» wchodzących w skład PE, a nie jednolitej reprezentacji «narodu Europy»"52. Czynności podjęte na podstawie art. 90 Konstytucji nie mogą być zatem traktowane jako pominięcie reguły suwerenności narodu (art. 4 Konstytucji), a w konsekwencji wybrani w Polsce deputowani są przedstawicielami „ «Narodu» Rzeczypospolitej Polskiej”53. W szczególności na tej podstawie wysoce wątpliwe byłoby, jako stanowiące naruszenie paradygmatu polskiego obywatelstwa (art. 34 ust. $1 \mathrm{w}$ związku z art. 4 Konstytucji), wyposażenie niepolskich obywateli UE w prawa wyborcze realizowane na terytorium państwa

47 P. Sarnecki, W sprawie procedury wyborczej do Parlamentu Europejskiego, „Przegląd Sejmowy" 2003, nr 5, s. 31.

48 J. Ciapała, Wokót pojmowania, op. cit., s. 86-87.

49 M. Kruk, Kształtowanie konstytucyjnych zasad członkostwa państwa w Unii Europejskiej (wybrane problemy), „Przegląd Sejmowy” 2010, nr 4, s. 55.

50 Wyrok TK z 31 maja 2004 r., sygn. akt K 15/04.

51 O doktrynalnych problemach dotyczących wyznaczenia relacji między reprezentantem i reprezentowanym na forum PE szerzej J. Szymanek, Stosunek, op. cit., s. 95-98. 
polskiego. W skrajnym przypadku mogłoby bowiem dojść do sytuacji, w której z Rzeczypospolitej nie zostałby wybrany ani jeden deputowany będący polskim obywatelem - przykład ten jest ekstremalny, niemniej ukazuje istotę problemu konstytucyjnego. Tym samym należy przyjąć, że w świetle Konstytucji, niepolscy obywatele UE nie są legitymowani do wykonywania czynnego i biernego prawa wyborczego do PE realizowanego w ramach jurysdykcji państwa polskiego. Inne rozumowanie wydaje się być co najmniej dyskursywne w odniesieniu do standardu wynikającego $\mathrm{z}$ art. 4 Konstytucji ${ }^{54}$.

$\mathrm{Na}$ marginesie należy jeszcze zauważyć, że traktatową regułą jest (proporcjonalnie) równorzędna pozycja wszystkich państw członkowskich wobec traktatów (art. 4 ust. 2 zdanie 1 in principio TUE) s5 $^{55}$ co w wymiarze politycznym musi być związane $\mathrm{z}$ zapewnieniem równowagi $\mathrm{w}$ kształtowaniu substratu osobowego poszczególnych organów unijnych. Zasada ta została zrealizowana chociażby w odniesieniu do Komisji Europejskiej, gdzie panel komisarzy jest równy liczbie państw członkowskich i z ich rekomendacji powoływanych (art. 17 ust. 5 TUE oraz modyfikacja wynikająca $\mathrm{z}$ aktu delegowanego ${ }^{56}$ ) lub, na analogicznych zasadach, na forum Trybunału Sprawiedliwości Unii Europejskiej (art. 19 ust. 2 zdanie drugie TUE). Postanowienia samych też traktatów, przy zastosowaniu zobiektywizowanej metody, przydzielają liczbę deputowanych, którzy z kolejnych państw członkowskich zasiadają w izbie europejskiej (art. 14 ust. 2 TUE oraz reguły wynikające $\mathrm{z}$ aktu delegowanego ${ }^{57}$ ). Operacja ta przydaje Parlamentowi Europejskiemu odpowiedniej legitymacji demokratycznej oraz nadaje mu cech organu pluralistycznego i republikańskiego, a taki cel, jak należy rozumieć, stanowił główne uzasadnienie wprowadzenia bezpośredniej elekcji członków izby europejskiej (art. 10 ust. 1 i 2 TUE), a które to zabiegi miały doprowadzić do możliwie szerokiego „sparlamentaryzowania” tego organu ${ }^{58}$. Przedmiotowy podział pozostaje także wyrazem uszanowana równoważnej roli państw w procesie decyzyjnym na forum UE oraz podkreśla ich podmiotowość na tym poziomie. Nie bardzo zatem wiadomo, dlaczego w odniesieniu do Parlamentu Europejskiego ta reguła, zasada uszanowania równoważnej pozycji suwerennych państw członkowskich, miałaby być zachwiana. Na płaszczyźnie funkcjonowania izby europejskiej odnajduje ona zresztą swój najgłębszy sens, dając wszystkim obywatelom państw członkowskich równoprawną możliwość decydowania o składzie osobowym PE lub też sprawowania w nim mandatu, a tym samym rozstrzygania

54 Odmiennie wyrok TK z 31 maja 2004 r., sygn. akt K 15/04.

55 Szerzej M. Kruk, Ksztattowanie, op. cit., s. 52-54.

56 Decyzja Rady Europejskiej z 22 maja 2013 r. w sprawie liczby członków Komisji Europejskiej (2013/272/UE), Dz.Urz. UE L 185 z 18 czerwca 2013 r.

57 Decyzja Rady Europejskiej (UE) 2018/937 z 28 czerwca 2018 r. ustanawiająca skład Parlamentu Europejskiego, Dz.Urz. UE L 165 z 2 lipca 2018 r.

58 J. Szymanek, Stosunek, op. cit., s. 94. 
o sprawach publicznych na poziomie unijnym ${ }^{59}$. Nabiera to tym większego znaczenia w sytuacji występowania wciąż dostrzegalnego zjawiska tzw. deficytu demokracji wewnątrz samej UE i to praktycznie od samych jej początków ${ }^{60}$, gdzie parlament jest jedynym w pełni przedstawicielskim organem działającym na tym poziomie, jako jedyny gwarantując na tej płaszczyźnie dochowanie mechanizmów demokracji partycypacyjnej ${ }^{61}$, a przez co powinien być w sposób możliwe optymalny ciałem reprezentatywnym dla poszczególnych państw członkowskich i poszczególnych obywateli z nich się wywodzących. Wybór deputowanych poza państwem narodowym, w sposób pomijający państwową i obywatelską ich przynależność, model ten zdaje się bezpośrednio niweczyć. De lege ferenda budzi to zresztą troskę o funkcjonalną spójność oraz wewnętrzną niesprzeczność samych traktatów i aktów wydanych w ich wykonaniu.

\section{Prawa wyborcze obywateli UE niebędącymi obywatelami polskimi w wyborach do samorządu gminnego}

Proces integracyjny położył akcent nie tylko na rozbudowę regulacji unijnych w dziedzinie szeroko pojętej materii gospodarczej, ale również wyznaczył silną pozycję obywateli UE w sferze praw politycznych. Świadczą o tym, wyżej przywołane, uprawnienia elekcyjne w wyborach do Parlamentu Europejskiego, ale również przyznanie ich na płaszczyźnie samorządowej ${ }^{62}$. Istotna między nimi różnica sprowadza się do tego, że bezpośredni wybór europejskich deputowanych jest podyktowany koniecznością zapewnienia demokratycznej legitymacji procesowi decyzyjnemu, $\mathrm{w}$ tym również prawodawczemu, na poziomie unijnym. Zagadnienie udziału obywateli UE w wyborach municypalnych związane jest natomiast $\mathrm{z}$ kwestią zaangażowania tych osób w procesy publiczne $\mathrm{w}$ miejscu ich rzeczywistego zamieszkania ${ }^{63}$. Chodzi tu bowiem o zbudowanie takiego otoczenia prawnego, które składało się będzie $\mathrm{z}$ instrumentów wzmacniających mechanizmy demokratyczne i partycypacyjne ${ }^{64}$. Ich zadaniem jest zapewnie-

59 Ideę PE, jako czynnika „obecności społecznej czy obywatelskiej”, szerzej przedstawia P. Sarnecki, W sprawie, op. cit., s. 30-31.

60

S. Konopacki, Dylematy, op. cit., s. 55.

${ }^{61}$ Szerzej M. Jabłoński, Demokracja partycypacyjna w Unii Europejskiej. Rozważania na tle wprowadzenia instytucji obywatelskiej inicjatywy ustawodawczej, „Przegląd Sejmowy" 2010, nr 4, s. 107-110, 119-121.

62 Szerzej A. Bodnar, A. Ploszka, Rozszerzenie czynnego i biernego prawa wyborczego $w$ wyborach samorzadowych na osoby nieposiadajace obywatelstwa Unii Europejskiej, „Samorząd Terytorialny” 2013, nr 9, s. 67-70.

63 Kwestia ta jest analizowana również poza kontynentem europejskim, o czym szerzej M. Rulka, Współczesne warunki, op. cit., s. 47-50, i przywołana tam literatura. Szerzej A. Piekutowska, Prawa, op. cit., s. 185-186. 
nie obywatelom UE możliwości wpływu na liczne czynności decyzyjne, które dotyczą ich bezpośrednio ${ }^{65}$, a wykonywane są na najniższym poziomie samorządu terytorialnego, przy jednoczesnym zastrzeżeniu warunku właściwego im na tym poziomie domicylu. Kwestię tę reguluje art. 22 ust. 1 zdanie pierwsze TFUE, w którym stwierdza się, że: „Każdy obywatel Unii mający miejsce zamieszkania w Państwie Członkowskim, którego nie jest obywatelem, ma prawo głosowania i kandydowania w wyborach lokalnych w Państwie Członkowskim, w którym ma miejsce zamieszkania, na takich samych zasadach jak obywatele tego państwa". Traktatowa konstrukcja tego prawa jest tożsama $\mathrm{z}$ regułami obowiązującymi na płaszczyźnie wykonywania uprawnień elekcyjnych do Parlamentu Europejskiego, a więc odnosi się do obywateli UE, powiązana jest z ich domicylem oraz powinna być realizowana na zasadach niedyskryminacji między obywatelami UE pochodzącymi z różnych państw członkowskich. Reguły te oraz pozostałe kwestie o charakterze ordynacyjnym zostały unormowane $\mathrm{w}$ dedykowanej temu zagadnieniu dyrektywie ${ }^{66}$. Jej postanowienia są o tyle istotne, że wprowadzają pewną dychotomię w uprawnieniach obywateli UE. Przewidują, że korzystają oni każdocześnie z czynnego i biernego prawa wyborczego w toku elekcji „członków samorządowych organów przedstawicielskich” i jednocześnie wprowadzają dodatkową limitację, o charakterze fakultatywnym, na mocy której państwa członkowskie „mogą zastrzec, że tylko ich obywatele mogą być wybierani na urząd kierownika organu wykonawczego" (art. 5 ust. 3 przywołanej dyrektywy). Model przewidziany przez kompleks tych przepisów zakłada, że obywatele UE mogą wykonywać prawa wyborcze na płaszczyźnie „wspólnoty lokalnej stopnia podstawowego", co w Polsce odnosi się do poziomu gminy, jako podstawowej jednostki samorządu terytorialnego (art. 164 ust. 1 Konstytucji). Publiczne zaangażowanie unijnych obywateli jest przez prawo UE poręczone zarówno w sferze czynnego, jak i biernego prawa wyborczego. Przywołana dyrektywa gwarantuje również partycypację jednostek w wyborze członków „samorządowych organów przedstawicielskich” oraz „kierownika i członków samorządowych organów wykonawczych", co przydaje tej regulacji charakteru kompleksowego, gdyż umożliwia wskazanie substratu osobowego wszystkich kategorii organów władzy samorządowej stopnia podstawowego ${ }^{67}$.

Zagadnienie przydania obywatelom UE prawa do udziału w wyborach lokalnych w państwie członkowskim, którego nie są obywatelami, przede wszystkim

65 Szerzej A. Feja-Paszkiewicz, Prawo głosowania i kandydowania w wyborach lokalnych - uwagi w kontekście członkostwa Polski w Unii Europejskiej, „Zeszyty Naukowe Państwowej Wyższej Szkoły Zawodowej im. Witelona w Legnicy” 2007, nr 1, s. 47-49.

Dyrektywa Rady 94/80/WE z 19 grudnia 1994 r. ustanawiająca szczegółowe warunki wykonywania prawa głosowania i kandydowania w wyborach lokalnych przez obywateli Unii mających miejsce zamieszkania w Państwie Członkowskim, którego nie są obywatelami, Dz.Urz. UE L 368 z 31 grudnia 1994 r.

67 Szerzej A. Feja-Paszkiewicz, Prawo, op. cit., s. 42-43. 
powinno być skonfrontowane w sferze zgodności takiego mechanizmu $\mathrm{z}$ art. 4 Konstytucji. Istotne jest na tym tle rozważenie, czy wykonywanie władzy na poziomie municypalnym jest elementem realizacji władzy zwierzchniej przez naród polski, czy też stanowi ona formę władztwa sui generis. Przede wszystkim należy wziąć pod uwagę, że art. 4 Konstytucji przywołuje suwerena i potwier$\mathrm{dza}, \dot{z ̇ e}$ sprawuje on całokształt władzy publicznej w Polsce. Przepis nie dokonuje żadnej pojęciowej kategoryzacji (rozróżnienia) tej władzy, a jedynie wskazuje jej źródło przez odniesie go do zbiorowości wszystkich polskich obywateli ${ }^{68}$. Jedyna dystynkcja, jaką ustrojodawca czyni, odwołuje się do bezpośredniego oraz delegowanego sposobu jej sprawowania. Intencją ustrojodawcy nie było zatem tworzenie kategorii władztwa publicznego, które wychodziłoby poza kompleks suwerennego uprawnienia narodu ${ }^{69}$. Tym samym, wykonywanie każdej jurysdykcji publicznej, bez względu na kategorię (rodzaj) organu, znajduje swoje umocowanie w woli narodu, co zresztą następnie znajduje swoje potwierdzenie w dalszych przepisach konstytucyjnych. W świetle art. 16 ust. 2 Konstytucji: „Samorząd terytorialny uczestniczy w sprawowaniu władzy publicznej [...]”, a także „wykonuje zadania publiczne nie zastrzeżone przez Konstytucję lub ustawy dla organów innych władz publicznych" (art. 163 Konstytucji) ${ }^{70}$. Oba przepisy mają fundamentalne znaczenie dla czynionych rozważań. Po pierwsze, odczytywane łącznie $z$ art. 15 Konstytucji ustanawiają ustrojową regułę dekoncentracji władzy publicznej w Polsce, a więc dokonują podziału na taki jej zakres, który ma być wykonywany na poziomie centralnym - rządowym (art. 146 ust. 2 Konstytucji), jak również zdecentralizowanym, a więc powierzonym administracji rządowej w województwie (art. 152 ust. 1 Konstytucji) oraz jednostkom samorządu terytorialnego (art. 16 ust. 2 Konstytucji) ${ }^{71}$. Po drugie, w wymiarze merytorycznym wyposażają samorząd municypalny w prawo uczestnictwa w sprawowaniu władztwa publicznego w ogóle, a także uznają jego względną samodzielność jurysdykcyjną w tym zakresie (art. 16 ust. 2 zdanie drugie Konstytucji). Po trzecie wreszcie, żaden z przywołanych przepisów nie przydaje organom jednostek samorządu terytorialnego jakiejkolwiek innej jurysdykcji niż ta, która mieści się w konstytucyjnej kategorii „władzy zwierzchniej”. Ustawa zasadnicza wyraźnie w tej mierze wskazuje, że samorząd „uczestniczy w sprawowaniu władzy publicznej” (art. 16 ust. 2 zdanie pierwsze in fine Konstytucji), a więc wykonuje tylko

68 Szerzej K. Kozłowski, Ewolucja pojęcia obywatelstwa w okresie obowiązywania Konstytucji RP z 1997 r. - zagadnienia wybrane [w:] Dwadzieścia lat obowiązywania Konstytucji RP. Polska myśl konstytucyjna a międzynarodowe standardy demokratyczne, red. J. Jaskiernia, K. Spryszak, Toruń 2017, s. 193-198.

Odmiennie wyrok TK z 11 maja 2005 r., sygn. akt K 18/04, OTK-A ZU 2005, nr 5, poz. 49. Szerzej wyrok TK z 26 lutego 2003 r., sygn. akt K 30/02, OTK-A ZU 2003, nr 2, poz. 16. Szerzej A. Skoczylas, W. Piątek, Komentarz do art. 15 [w:] Konstytucja RP. Komentarz, t. I, Art. 1-86, red. M. Safjan, L. Bosek, Warszawa 2016, s. 397-411. 
takie imperium, które w art. 4 Konstytucji zostało unormowane ${ }^{72}$. Odmienne rozumowanie musiałoby zakładać istnienie jakiegoś odrębnego kategorialnie władztwa, wykonywanego poza suwerennością narodu, a w wymiarze funkcjonalnym - jako że rozpatrujemy kwestie działania samorządu terytorialnego jeszcze godzącego w zasadę jednolitości państwa polskiego (art. 3 Konstytucji) ${ }^{73}$. Samorząd dysponuje tym samym władzą o takim samym pochodzeniu (źródle), jaką mają organy rządowe. Odróżnia go jedynie to, że ma szczególną rolę, bo prowadzi polityki w sprawach, które dotyczą podstawowych potrzeb obywateli i ich wspólnot (art. 166 ust. $1 \mathrm{w}$ związku z art. 16 ust. 2 Konstytucji). Zogniskowanie aktywności na tych codziennych (powszednich) sprawach nie jest natomiast powodem dla ich ustrojowego przeciwstawienia sferze działania narodu polskiego ${ }^{74}$, co oznacza, że nawet operacjonalizacja zadań własnych (art. 16 ust. 2 zdanie drugie Konstytucji) nadal pozostaje w reżimie realizacji „władzy zwierzchniej" (art. 4 ust. 1 Konstytucji) ${ }^{75}$. Co więcej, z samego tylko faktu, że gminna wspólnota samorządowa wykonuje zadania na rzecz wszystkich mieszkańców, w tym obywateli i cudzoziemców, nie wynika, aby ci ostatni - już tylko przez samą okoliczność legitymowania się określonym domicylem oraz będąc beneficjentami tych polityk - zyskiwali prawa polityczne na omawianym pozio$\mathrm{mie}^{76}$. Musi bowiem istnieć ten dodatkowy, obywatelski łącznik, jakiś osobowy substrat suwerenności, który dopiero kształtuje umocowanie do sprawowania władzy publicznej, także w wymiarze lokalnym.

Reasumując tę część rozważań, warto wskazać, że art. 4 Konstytucji swoim zakresem obejmuje każdy aspekt wykonywania na terytorium Rzeczypospolitej „władzy zwierzchniej”. Jurysdykcja samorządu terytorialnego w tym paradygmacie $\mathrm{w}$ pełni się mieści ${ }^{77}$. Nie ma zatem prawnie uzasadnionego powodu, dla którego nie należałoby uznawać, że również samorząd gminny tą regułą objęty nie jest, nawet jeżeli jest "podstawową jednostką samorządu terytorialnego" (art. 164 ust. 1 Konstytucji), a co więcej - jest jedną z kilku form wykonywania władzy municypalnej (art. 164 ust. 2 Konstytucji). Przyznanie osobom, które nie są polskimi obywatelami, a przez to nie mieszczą się w kategorii narodu polskiego, rozumianego przez pryzmat konglomeratu polskich obywateli, czynnego i (względnie pełnego) biernego prawa wyborczego, jest równoznaczne z przekazaniem im uprawnień do realizacji „władzy zwierzchniej w Rzeczypospolitej”,

72 Odmiennie K. Działocha, Zgodność, op. cit., s. 19.

73 Podobnie wyrok TK z 18 lutego 2003 r., sygn. akt K 24/02, OTK-A ZU 2003, nr 2, poz. 11.

74 Odmiennie z powołaniem na art. 16 ust. 2 Konstytucji K. Działocha, Zgodność, op. cit., s. 19.

75 Podobnie wyrok TK z 18 lutego 2003 r., sygn. akt K 24/02.

76 Odmiennie W. Skrzydło, Konstytucja Rzeczypospolitej Polskiej. Komentarz, Warszawa 2009, s. 25.

77 Podobnie G. Kryszeń, K. Prokop, Aksjologia, op. cit., s. 78. 
co następuje $\mathrm{z}$ naruszeniem standardu określonego w art. 4 Konstytucji ${ }^{78}$. Cudzoziemcy, nawet będący obywatelami UE, nie mieszczą się w konstytucyjnej kategorii obywateli polskich, po prostu tego przymiotu nie mają, nie mają tym samym prawnego umocowania do sprawowania władzy publicznej w Polsce, zarówno na poziomie rządowym, jak również samorządowym ${ }^{79}$.

Przyznanie obywatelom UE niebędącym obywatelami polskimi uprawnień wyborczych na poziomie samorządu gminnego narusza nie tylko standard wynikający z art. 4 Konstytucji. Pozostaje również niezgodne z innymi przepisami ustawy zasadniczej. Teza ta wymaga jednak dwupłaszczyznowej analizy, która uzależniona jest od rodzaju (kategorii) zagwarantowanego im prawa wyborczego. Było już wskazane, że prawo unijne przewiduje dla obywateli UE możliwość realizacji czynnego i (względnie pełnego) biernego prawa wyborczego do samorządu terytorialnego najniższego szczebla. Oba uprawnienia zostały im następnie przypisane we właściwych postanowieniach polskiego Kodeksu wyborczego ${ }^{80}$. Przede wszystkim regulacje przewidują możliwość wyboru członków rady gminy (organu stanowiącego) (art. $10 \$ 1$ pkt 3 lit. a k.w.) oraz wójta (burmistrza, prezydenta), będącego organem wykonawczym (art. $10 \$ 1$ pkt 4 k.w.), a więc realizację prawa wybierania. Pozostaje to jednak w bezpośredniej sprzeczności z art. 62 ust. 1 Konstytucji, który przewiduje, że „obywatel polski ma prawo [...] wybierania przedstawicieli do organów samorządu terytorialnego [...]”. Przepis ten jest wyjątkowo jasny od strony semantycznej. Definiuje bowiem uprawnienia elekcyjne obywateli polskich w sposób wyłączny, a sama jego formalna konstrukcja odwołuje się od kategorii katalogu zamkniętego. Nie pozwala to na jakąkolwiek ekstensywną jego wykładnię, gdyż stanowiłoby to wyjście poza wyraźną wolę ustrojodawcy $^{81}$. Zważyć także należy, że prawodawca konstytucyjny niezwykle świadomie posługuje się kategoriami podmiotowymi, a więc pojęciami „obywateli”, „Polaków”, „cudzoziemców” czy wszystkich ludzi („każdy”), przypisując im jednocześnie określony zespół praw i obowiązków. W tym też kontekście ustawa zasadnicza przyznaje czynne prawo elekcyjne w wyborach samorządowych jedynie obywatelom polskim, a nie czyni tego wobec innych osób, w tym obywateli $\mathrm{UE}^{82}$. Skoro zaś takiego rozróżniania nie ma na poziomie konstytucyjnym, toteż, w świetle reguły lege non distinguente, ustawodawca zwykły czynić go w postano-

78 Odmiennie wyrok TK z 11 maja 2005 r., sygn. akt K 18/04.

79 Niektórzy autorzy, z przywołaniem konwencji Rady Europy, sugerują jednak odejście od paradygmatu narodowego w kontekście lokalnych praw wyborczych, np. A. Bodnar, A. Ploszka, Rozszerzenie, op. cit., s. 71-73.

80 Ustawa z 5 stycznia 2011 r. - Kodeks wyborczy, tj. Dz.U. 2019, poz. 684, ze zm.; dalej: k.w.

81 Odmiennie K. Działocha, Zgodność, op. cit., s. 16-19.

82 Podobnie P. Radziewicz, Opinia w sprawie zgodności z Konstytucja przepisu ustawy umożliwiającego cudzoziemcom - obywatelom Unii Europejskiej - wzięcie udziału w wyborach samorządowych w Polsce, „Przegląd Sejmowy” 2005, nr 2, s. 171-175. 
wieniach ordynacyjnych nie powinien ${ }^{83}$. Już tylko na marginesie należy wskazać, że językowo zamkniętego brzmienia art. 62 ust. 1 Konstytucji, a przez to potrzeby „restryktywnego” jego odczytania ${ }^{84}$, nie da się przełamać ogólną regułą otwartości polskiego systemu prawnego na prawo międzynarodowe, w tym unormowania unijne (art. 9 Konstytucji) lub też nawet „życzliwą prawu unijnemu” wykładnią polskiej Konstytucji ${ }^{85}$. Czym innym jest bowiem nakaz przestrzegania prawa zewnętrznego, a czym innym najwyższa moc obowiązująca ustawy zasadniczej (art. 8 Konstytucji).

Drugi aspekt dotyczy biernego prawa wyborczego, a więc możliwości bycia wybranym do organów stanowiących - choć już nie wykonawczych (art. $11 \S 1$ pkt 5 i 6 k.w.) - samorządu gminnego, jakie przysługuje niepolskim obywatelom UE. Wskazać trzeba, że problem ten nie został uregulowany w art. 62 ust. 1 Konstytucji, gdyż swoim zakresem normowania obejmuje wyłącznie czynne prawo elekcyjne. Jednak również i w tym zakresie standard konstytucyjny zdaje się być naruszony przez obowiązujące postanowienia kodeksowe. Przede wszystkim zauważyć można, że sprawowanie publicznej jurysdykcji w samorządzie gminnym stanowi wykonywanie „władzy zwierzchniej”, a tym samym stoi w sprzeczności z art. 4 Konstytucji w odniesieniu do tych samych reguł, które w niniejszym opracowaniu zostały już przeanalizowane i zachowują swoją adekwatność. Co więcej, wykonanie biernego prawa wyborczego, skutkującego objęciem mandatu przedstawicielskiego (radny - członek organu stanowiącego) stanowi, w wymiarze jakościowym, jeszcze głębszą ingerencję w sferę zastrzeżoną dla polskiego suwerena, aniżeli tylko w przypadku realizacji prawa wybierania. Wiąże się bowiem $\mathrm{z}$ bezpośrednim sprawowaniem władzy publicznej wobec wszystkich uczestników obrotu prawnego i to w codziennym wymiarze funkcjonowania samorządu lokalnego. Wpływ cudzoziemca na realizację spraw publicznych, w tym również aktualizację sytuacji prawnej polskich obywateli, jest w tej sferze nieporównywalnie większy, silniej oddziałujący, aniżeli w przypadku wykonywania czynnego prawa wyborczego. Zdaje się zresztą, że poziom wpływu władzy lokalnej na prawną kondycję jednostki, w tym kwestie własnościowe, podatkowe i porządkowe, jest dużo bardziej intensywny niż czyniony z perspektywy władzy

83 Niektórzy przedstawiciele doktryny nie tylko akceptują pogląd o dopuszczalności wykonywania przez niepolskich obywateli UE praw wyborczych w wyborach municypalnych, jak również aprobują rozszerzenie tego przywileju na prawo uczestnictwa w referendum lokalnym, a także zdają się przychylnie odnosić do przyznania praw wyborczych i referendalnych "pozostałym cudzoziemcom oraz apatrydom legalnie mieszkającym na terytorium polskiej gminy", np. A. Feja-Paszkiewicz, Prawo, op. cit., s. $46-47$.

84 Szerzej L. Garlicki, Opinia w sprawie zgodności z Konstytucja przepisu ustawy umożliwiającego cudzoziemcom - obywatelom Unii Europejskiej - wzięcie udziału w wyborach samorzadowych $w$ Polsce, „Przegląd Sejmowy” 2005, nr 2, s. 168.

85 Odmiennie A. Bodnar, A. Ploszka, Rozszerzenie, op. cit., s. 69, 74. 
rządowej (art. 94 Konstytucji) ${ }^{86}$. Nie chodzi tu przy tym, choć również, tylko o wartości chronione na mocy art. 5 Konstytucji, ale też o zagwarantowanie pozycji prawnej jednostek w ramach takiego standardu, jaki w ustawie zasadniczej został dla nich przewidziany (art. 30 Konstytucji) ${ }^{87}$. Na tym tle należy jeszcze zauważyć, że obowiązująca ustawa zasadnicza, przede wszystkim ze względu na gorzkie doświadczenia historyczne polskiej państwowości, ufundowana jest na pewnej ustrojowej wrażliwości na potrzebę „strzeżenia niepodległości [...] [oraz - dopisek K.K.] bezpieczeństwa obywateli” (art. 5 Konstytucji) ${ }^{88}$. Poza kwalifikowanym przypadkiem określonym w art. 91 ust. 3 Konstytucji ustawa zasadnicza nie zakłada umocowania podmiotów zewnętrznych do wykonywania szczególnej prawnej jurysdykcji nad państwem polskim i jego obywatelami. Skoro zatem ustrojodawca nie przewiduje dla cudzoziemców czynnego prawa wyborczego, które wiąże się z mniejszą eksploatacją polskiej suwerenności, toteż tym bardziej, w świetle standardu konstytucyjnego, nie przyznaje im prawa do biernego wykonywania jurysdykcji publicznej (w odniesieniu do objęcia mandatu w organie stanowiącym samorządu gminnego), która jest kategorialnie bardziej pogłębioną formą wykonywania władzy zwierzchniej (art. 4 Konstytucji).

Należy przy tym dodatkowo podkreślić, że nie ma prawnego znaczenia dla niniejszej konkluzji fakt, że Konstytucja - w przeciwieństwie do centralnych konstytucyjnych organów państwa - nie reguluje biernego prawa wyborczego w procedurze elekcji do organów samorządu terytorialnego, odsyłając do unormowania tej kwestii na poziomie ustawowym (art. 169 ust. 2 i 3 Konstytucji) ${ }^{89}$. Zdaje się to wynikać przede wszystkim z dwóch okoliczności, które mają czysto pragmatyczny i organizacyjny charakter. Po pierwsze, w wymiarze legislacyjnym nie było to możliwe ze względu na fakt, że centralne organy państwa są w ustawie zasadniczej wyraźnie (nominalnie) określone, przez co da się przyporządkować im określony reżim ich wyboru. Tymczasem, poza gminą, dokonanie kategoryzacji szczebli samorządu terytorialnego również zostało odesłane na poziom ustawy (art. 164 ust. 2 Konstytucji), która tym samym staje się płaszczyzną właściwą dla określenia odnośnych reguł wyborczych. Po drugie, ta ostatnia czynność nie jest jednak objęta całkowitą dowolnością działania ustawodawcy zwykłego, którego cały czas wiąże standard konstytucyjny, w tym przede wszystkim reguła wynikająca $\mathrm{z}$ art. 4 Konstytucji oraz wnioskowanie oparte na łącznym ujęciu art. 62 ust. $1 \mathrm{w}$ związku $\mathrm{z}$ art. 5 Konstytucji.

86 Szerzej J. Parysek, Rola lokalnego samorzadu terytorialnego w rozwoju społeczno-gospodarczym i przestrzennym gmin, „Ruch Prawniczy, Ekonomiczny i Socjologiczny” 2015, nr 3, s. 27-46.

87 Odmiennie wyrok TK z 11 maja 2005 r., sygn. akt K 18/04.

88 Szerzej o charakterze omawianego przepisu P. Tuleja, Komentarz do art. 5 [w:] Konstytucja Rzeczypospolitej Polskiej. Komentarz, red. P. Tuleja, 2019, LEX.

89

Odmiennie L. Garlicki, Opinia, op. cit., s. 168. 


\section{- Rozważania na zakończenie - niekonstytucyjność uprawnień wyborczych albo uznanie dorozumianej zmiany Konstytucji RP}

Dotychczasowe rozważania mogą być uznane za obarczone mankamentem natury temporalnej. Odwołują się bowiem do pewnych, przypuszczalnie dyskusyjnych, ustaleń dogmatycznych, abstrahując przy tym od prawnej rzeczywistości, w tym ujęcia mechanizmów czynnego i biernego prawa wyborczego obywateli UE jako instytucji w polskim systemie prawnym już dość wyraźnie zastanej. Obudowana jest już ona pewną praktyką i, jak się wydaje, do pewnego stopnia objęta konsensusem politycznym. Omawiane prawa elekcyjne zostały również potwierdzone, jako spełniające standard wynikający z ustawy zasadniczej, przez orzeczenia Trybunału Konstytucyjnego $^{90}$. Te ostatnie, co oczywiste, mają moc powszechnie obowiązującą i są ostateczne. Trudno jest przy tym nie zauważyć, że argumentacja podniesiona przez sąd konstytucyjny w odnośnych sprawach sprowadzała się raczej do dokonania, choć nie do końca nazwanej, prounijnej wykładni przepisów prawa ${ }^{91}$, której źródeł należy poszukiwać w art. 9 Konstytucji i płynącej z niego reguły przychylności wobec prawa międzynarodowego, co nabiera dodatkowego wzmocnienia w kontekście obowiązywania art. 90 Konstytucji ${ }^{92}$. Biorąc tę regułę pod uwagę, Trybunał Konstytucyjny uznawał konstytucyjność wymogów prawa unijnego (traktat akcesyjny) lub krajowych przepisów to prawo wykonujących (ustawowe przepisy ordynacyjne). Przedmiotem odrębnego opracowania mogłoby być jednak ustalenie, czy prounijna wykładania przepisów mogłaby w ogóle mieć miejsce w rozpatrywanych sprawach, w szczególności gdy odnośne przepisy konstytucyjne zdają się być językowo klarowne (jednoznaczne) i do tego jeszcze wzmocnione poważnymi argumentami natury systemowej. Warto już teraz wskazać, że w tej sytuacji sama „potrzeba integracji”" nie wydaje się być wartością przesądzającą o zasadności zastosowania wykładni prounijnej, skoro sama ustawa zasadnicza - ze względu na swoje wyraźne w tej mierze postanowienia - zdaje się ten problem konstytucyjny jednoznacznie rozwiązywać ${ }^{94}$.

Celem zachowania przejrzystości dialogu naukowego - w ramach zdania polemicznego względem dotychczasowego orzecznictwa konstytucyjnego - warto

90 Wyrok TK z 31 maja 2004 r., sygn. akt K 15/04, oraz z 11 maja 2005 r., sygn. akt K 18/04.

91 Szeroko i trafnie o tej metodzie, również w wymiarze systemowym, W. Rowiński, $\mathrm{Na-}$ kaz dokonywania wykładni prounijnej jako dyrektywa wykładni systemowej, „Ruch Prawniczy, Ekonomiczny i Socjologiczny" 2016, nr 1, s. 99-111.

92 Orzecznictwo konstytucyjne silnie akcentuje konsekwencje obowiązywania art. 90 Konstytucji, por. dla przykładu: wyrok TK z 27 maja 2003 r., sygn. akt K 11/03, OTK-A ZU 2003, nr 5, poz. 43.

93 Odmiennie K. Wojtyczek, Przekazywanie, op. cit., s. 114.

94 W orzecznictwie konstytucyjnym można dostrzec tezę jednak o silne przywiązanie do nadrzędnej roli językowej wykładni przepisów Konstytucji, również względem prawa unijnego, o czym dla przykładu: wyrok TK z 11 maja 2005 r., sygn. akt K 18/04. 
wskazać, że politycznie upodmiotowienie niepolskich obywateli UE w polskim systemie prawnym, przez przydanie im niektórych uprawnień wyborczych, zdaje się jednak nie korespondować ze standardem konstytucyjnym z przyczyn wskazanych w niniejszym artykule. Wszelkie następcze próby sanowania tego stanu rzeczy, a z takimi do tej pory mieliśmy do czynienia, pozostają oczywiście niezwykle wartościowe z poznawczego punktu widzenia. Bezsprzecznie, jak to ma miejsce w odniesieniu do orzecznictwa konstytucyjnego, miały swój „moment konstytucyjny" "95, jak również doniosłe racje ustrojowe i społeczne z tymi rozstrzygnięciami powiązane ${ }^{96}$. Niemniej w ślad za obserwacjami historycznymi ${ }^{97}$ budzą one i nadal budzić będą wątpliwości, gdy horyzont rozważań wyznaczać będzie obowiązująca ustawa zasadnicza, pozostawiona w niezmiennym kształ$\mathrm{cie}^{98} . \mathrm{Z}$ tej perspektywy można wyrazić zaniepokojenie, że ów spór konstytucyjny nie został rozwiązany z uwzględnieniem podobnej metodologii, z jakiej skorzystano przy okazji badania zgodności z Konstytucją przepisów Kodeksu postępowania karnego implementujących decyzję ramową ws. Europejskiego Nakazu Aresztowania ${ }^{99}$. W orzeczeniu tym Trybunał Konstytucyjny bardzo roztropnie rozważył relacje zachodzące między prawem unijnym a polską ustawą konstytucyjną, potwierdzając prymat tej ostatniej. Jednocześnie kierując się jej aksjologią, w tym również regułą wynikającą z art. 9 Konstytucji, przypomniał o naszych niekwestionowanych zobowiązaniach wynikających z członkostwa w UE ${ }^{100}$. Sprawa zakończyła się przyjęciem noweli konstytucyjnej, na mocy której ustrojodawca bardzo świadomie zrezygnował $\mathrm{z}$ dotychczasowego brzmienia ustawy zasadniczej na rzecz uczynienia zadość potrzebie integracyjnej ${ }^{101}$. Decyzja ta była zrozumiała i wpłynęła niesłychanie porządkująco na nasz system prawny, jak również miała przełomowe znaczenie w określeniu relacji ustrojowych między Rzecząpospolitą a Unią Europejską. Sam proces przyjęcia noweli konstytucyjnej był przy

95 Podobnie, z przywołaniem argumentu „opóźnienia w procesie akcesji Polski do UE, a co za tym idzie, uniemożliwienia przystąpienia Polski do UE” w planowanym terminie A. Bodnar, A. Ploszka, Rozszerzenie, op. cit., s. 69.

Wpływ kontekstu społecznego i politycznego na orzecznictwo TK analizuje D. Minich, Polityczny kontekst orzecznictwa Trybunału Konstytucyjnego, „Przegląd Prawa Publicznego 2017, nr 7-8, s. 11-20.

97 W literaturze przywołuje się wydarzenie, kiedy przedakcesyjna nowela samorządowej ordynacji wyborczej ostała się przed odrzuceniem w pierwszym czytaniu tylko jednym głosem przewagi, o czym szerzej K. Działocha, Zgodność, op. cit., s. 13-14.

98 P. Sarnecki, Regulacje, op. cit., s. 12.

99 Szerzej K. Kozłowski, Podstawy ekstradycji obywatela polskiego w znowelizowanym art. 55 Konstytucji RP wobec wymogów Europejskiego Nakazu Aresztowania - głos $w$ dyskusji, „Przegląd Legislacyjny” 2018, nr 4, s. 9-38.

100 Wyrok TK z 27 kwietnia 2005 r., sygn. akt P 1/05, OTK-A ZU 2005, nr 4, poz. 42.

101 Ustawa z 8 września 2006 r. o zmianie Konstytucji Rzeczypospolitej Polskiej, Dz.U. nr 200, poz. 1471. 
tym przeprowadzony publicznie, w sposób transparentny, a sama decyzja legislacyjna objęta pełną świadomością parlamentarzystów oraz, za ich pośrednictwem, obywateli. Wydaje się, że ten wzorzec rozwiązania problemu konstytucyjnego powinien znaleźć zastosowanie również w odniesieniu do zagadnienia będącego przedmiotem rozważań w niniejszym artykule. Jest to bowiem kwestia uczynienia zadość nie tylko ustaleniom dogmatycznym, ale również mająca niebagatelny wpływ na poziom społecznej akceptacji samego procesu integracyjnego i zbędnego tworzenia powodów do jego kontestacji w przestrzeni publicznej.

Zarysowane wątpliwości konstytucyjne mogą być usunięte nie tylko na poziomie interwencji prawodawczej w sposób skutkujący legislacyjną zmianą obowiązującej ustawy zasadniczej, co de lege fundamentali ferenda należałoby ustrojodawcy zasugerować. Argumenty stojące za ingerencją prawodawczą są w tym przypadku dość silne i na pewno nie są „determinowane jedynie kontekstem sytuacyjno-politycznym”, jak również trudno im zarzucić cechę „doraźności” lub „pochopności” ${ }^{102}$. Inną kwestią, zapewne do rozważenia, jest pozostawienie obecnego stanu prawnego, odwołującego się do wspominanej już kategorii mechanizmów zastanych, i przyznanie, że w wyniku ratyfikacji traktatu akcesyjnego doszło do dorozumianej zmiany Konstytucji RP. Koncepcja ta odnotowana jest przez orzecznictwo konstytucyjne ${ }^{103}$ i znana jest literaturze ${ }^{104}$. Warto tylko przypomnieć, że przystąpienie Polski do UE, a tym samym przyznanie niepolskim obywatelom UE praw elekcyjnych w wyborach do samorządu lokalnego oraz do Parlamentu Europejskiego, odbyło się z zastosowaniem szczególnej procedury konstytucyjnej, która została określona w art. 90 Konstytucji ${ }^{105}$. W wymiarze formalnym przewiduje ona konieczność uchwalenia ustawy upoważniającej prezydenta do ratyfikowania przedmiotowej umowy większością kwalifikowaną 2/3 ustawowej liczby odnośnych parlamentarzystów, zarówno w Sejmie, jak i w Senacie (art. 90 ust. 2 Konstytucji). Jest to wielkość bardziej znacząca niż wymagana do zmiany Konstytucji, gdzie wystarczy spełnienie warunku uzyskania $2 / 3$ głosów w izbie niższej oraz bezwzględnej większości w izbie senackiej - przy zastrzeże-

102 J. Szymanek, Determinanty procesu zmiany konstytucji, „Przegląd Legislacyjny” 2015, nr 3, s. 9, 16-17.

103 Choć nie jest przez nie akceptowana: wyrok TK z 24 listopada 2010 r., sygn. akt K 32/09, OTK-A ZU 2010, nr 9, poz. 108.

104 M. Laskowska, Tryb zmiany konstytucji w Polsce (ze szczególnym uwzględnieniem nowych elementów proceduralnych i praktyki) [w:] Tryb zmiany konstytucji w wybranych państwach członkowskich Unii Europejskiej, red. K. Kubuj, J. Wawrzyniak, Warszawa 2010, s. 128-130.

105 Szerzej M. Masternak-Kubiak, Dopuszczalność nieformalnej zmiany Konstytucji RP (uwagi w kontekście prawa wyborczego obywateli Unii Europejskiej) [w:] Prawo w słuzbie państwu i społeczeństwu. Prace dedykowane Profesorowi Kazimierzowi Działosze z okazji osiemdziesiątych urodzin, red. B. Banaszak, M. Jabłoński, S. Jarosz-Żukowska, Wrocław 2012, s. 116-132. 
niu ustawowego quorum (art. 235 ust. 4 Konstytucji) ${ }^{106}$. Co więcej, traktat akcesyjny został przyjęty nie tyle na mocy tej szczególnej decyzji parlamentarnej, ile przez odwołanie się do woli samego suwerena, wyrażonej w drodze kwalifikowanego referendum prawodawczego (art. 90 ust. 3 i 4 Konstytucji), który w tym wypadku skorzystał z możliwości bezpośredniego wykonania swojego najwyższego zwierzchnictwa (art. 4 ust. 2 Konstytucji). Decyzja akcesyjna, skutkująca „europeizacją” porządku prawnego państwa członkowskiego, może być zatem potraktowana jako doniosłe postanowienie co do jeszcze większej „internacjonalizacji” naszej ustawy zasadniczej ${ }^{107}$, a tym samym zawierać w sobie nakaz reinterpretacji art. 4 i 62 ust. 1 Konstytucji. Tego faktu w wymiarze konstytucyjnym i politycznym pominąć się nie da, bo powodowałoby to konieczność uznania, że w przypadku wyborów do Parlamentu Europejskiego oraz wyborów lokalnych - do samorządu gminnego, doszło do świadomego i stałego „przełamania” dotychczasowych reguł ustrojowych, jako uznania roli procesu integracyjnego w określeniu ustrojowego kształtu państwa ${ }^{108}$. Taka forma dorozumianej zmiany Konstytucji mogłaby być uznana za czyniącą zadość zastrzeżeniom natury konstytucyjnej, które zostały przywołane w niniejszym opracowaniu. Zawsze jednak, w takim wypadku, pozostanie wątpliwość co do nieprzekraczalnych granic (prawny limes) ${ }^{109}$ dopuszczalnych merytorycznych zmian ustawy zasadniczej w wykonaniu zasady przychylności Polski dla integracji europejskiej. Równie istotna pozostaje także kwestia ostatecznego kształtu normatywnego obowiązującego ustroju konstytucyjnego, gwarancyjnego charakteru „spisanej” karty konstytucyjnej (Konstytucji) oraz, co chyba najważniejsze, wyznaczenia akceptowalnych ustrojowo, politycznie i społecznie granic procesu integracyjnego.

\section{Bibliografia}

Adamczyk J., Pojęcie i znaczenie obywatelstwa, „Studia Prawnicze i Administracyjne” 2018, nr 3.

Bodnar A., Ploszka A., Rozszerzenie czynnego i biernego prawa wyborczego w wyborach samorządowych na osoby nieposiadające obywatelstwa Unii Europejskiej, „Samorząd Terytorialny" 2013, nr 9.

Ciapała J., Wokół pojmowania i wykonywania suwerenności $w$ warunkach członkostwa w Unii Europejskiej - kilka uwag podstawowych, lecz czy przekonujących?, „Gdańskie Studia Prawnicze” 2014, t. 31.

106 Zwraca na to również uwagę K. Działocha, Zgodność, op. cit., s. 20.

107 J. Szymanek, Determinanty, op. cit., s. 28-30.

108 A. Kustra, „Euronowelizacja” w projektach ustaw o zmianie Konstytucji RP. Próba oceny, „Przegląd Sejmowy” 2011, nr 3, s. 32.

109 Taki katalog formułuje J. Ciapała, Wokót pojmowania, op. cit., s. 89. 
Czapliński W., Prawo wspólnotowe a prawo wewnętrzne w praktyce sądów konstytucyjnych państw członkowskich (wybrane zagadnienia), „Kwartalnik Prawa Publicznego” 2004, nr 2.

Działocha K., Zgodność zmian w prawie wyborczym z Konstytucją RP (w związku z przystapieniem Polski do Unii Europejskiej), „Państwo i Prawo” 2003, z. 11.

Feja-Paszkiewicz A., Prawo głosowania i kandydowania $w$ wyborach lokalnych - uwagi w kontekście członkostwa Polski w Unii Europejskiej, „Zeszyty Naukowe Państwowej Wyższej Szkoły Zawodowej im. Witelona w Legnicy" 2007, nr 1.

Garlicki L., Opinia w sprawie zgodności z Konstytucja przepisu ustawy umożliwiającego cudzoziemcom - obywatelom Unii Europejskiej - wzięcie udziału w wyborach samorzadowych w Polsce, „Przegląd Sejmowy” 2005, nr 2.

Harasimiuk D., Obywatelstwo UE - element tożsamości narodowej, europejskiej, czy jedynie dodatkowy status obywateli państw członkowskich?, „Ius Novum” 2017, nr 3.

Jabłoński M., Demokracja partycypacyjna w Unii Europejskiej. Rozważania na tle wprowadzenia instytucji obywatelskiej inicjatywy ustawodawczej, „Przegląd Sejmowy 2010, nr 4.

Konopacki S., Dylematy obywatelstwa europejskiego, „Studia Europejskie” 2003, nr 4.

Kozłowski K., Ewolucja pojęcia obywatelstwa w okresie obowiązywania Konstytucji RP z 1997 r. - zagadnienia wybrane [w:] Dwadzieścia lat obowiąywania Konstytucji RP. Polska myśl konstytucyjna a międzynarodowe standardy demokratyczne, red. J. Jaskiernia, K. Spryszak, Toruń 2017.

Kozłowski K., Gwarancja prawa do opieki dyplomatycznej i konsularnej jako element instytucji obywatelstwa Unii Europejskiej [w:] Dookoła Wojtek. Księga pamiątkowa poświęcona Doktorowi Arturowi Preisnerowi, red. R. Balicki, M. Jabłoński, Wrocław 2018.

Kozłowski K., Podstawy ekstradycji obywatela polskiego w znowelizowanym art. 55 Konstytucji RP wobec wymogów Europejskiego Nakazu Aresztowania - głos w dyskusji, „Przegląd Legislacyjny" 2018, nr 4.

Kozłowski K., Prawo petycji do Parlamentu Europejskiego jako instrument pozasądowej ochrony praw i wolności [w:] Pozasądowa ochrona praw i wolności jednostki - instytucje, standardy, efektywność, red. E. Wójcicka, Częstochowa 2014.

Kruk M., Kształtowanie konstytucyjnych zasad członkostwa państwa w Unii Europejskiej (wybrane problemy), „Przegląd Sejmowy” 2010, nr 4.

Kryszeń G., Prokop K., Aksjologia polskiej Konstytucji, Warszawa 2017.

Kustra A., „Euronowelizacja” w projektach ustaw o zmianie Konstytucji RP. Próba oceny, „Przegląd Sejmowy” 2011, nr 3.

Laskowska M., Tryb zmiany konstytucji w Polsce (ze szczególnym uwzględnieniem nowych elementów proceduralnych i praktyki) [w:] Tryb zmiany konstytucji w wybranych państwach członkowskich Unii Europejskiej, red. K. Kubuj, J. Wawrzyniak, Warszawa 2010.

Małajny I., Konstytucja - rodzaje i koncepcje, „Gdańskie Studia Prawnicze” 2014, t. 31.

Małajny R., Pojęcie konstytucji, „Państwo i Prawo” 2018, z. 2.

Masternak-Kubiak M., Dopuszczalność nieformalnej zmiany Konstytucji RP (uwagi $w$ kontekście prawa wyborczego obywateli Unii Europejskiej) [w:] Prawo w służbie państwu i społeczeństwu. Prace dedykowane Profesorowi Kazimierzowi Działosze z okazji 
osiemdziesiątych urodzin, red. B. Banaszak, M. Jabłoński, S. Jarosz-Żukowska, Wroclaw 2012.

Mik C., Umocnienie legitymacji demokratycznej Unii Europejskiej [w:] Traktat z Lizbony. Główne reformy ustrojowe Unii Europejskiej, red. J. Barcz, Warszawa 2008.

Minich D., Polityczny kontekst orzecznictwa Trybunału Konstytucyjnego, „Przegląd Prawa Publicznego" 2017, nr 7-8.

Parchimowicz I., Prawo do wystapienia z Unii Europejskiej na przykładzie Brexitu, „Europejski Przegląd Sądowy” 2017, nr 9.

Parysek J., Rola lokalnego samorządu terytorialnego w rozwoju społeczno-gospodarczym i przestrzennym gmin, „Ruch Prawniczy, Ekonomiczny i Socjologiczny” 2015, nr 3, https://doi.org/10.14746/rpeis.2015.77.3.4.

Piekutowska A., Prawa wyborcze imigrantów. Refleksje na tle instytucji obywatelstwa europejskiego, „Białostockie Studia Prawnicze” 2016, t. 20, https://doi.org/10.15290/ bsp.2016.20a.13.

Radziewicz P., Opinia w sprawie zgodności z Konstytucja przepisu ustawy umożliwiajacego cudzoziemcom - obywatelom Unii Europejskiej - wzięcie udziału w wyborach samorzadowych w Polsce, „Przegląd Sejmowy” 2005, nr 2.

Rowiński W., Nakaz dokonywania wykładni prounijnej jako dyrektywa wykładni systemowej, „Ruch Prawniczy, Ekonomiczny i Socjologiczny” 2016, nr 1, https://doi. org/10.14746/rpeis.2016.78.1.9.

Rulka M., Regulacja wyborów do Parlamentu Europejskiego w prawie Unii Europejskiej, „Studia Wyborcze” 2013, t. 16.

Rulka M., Współczesne warunki posiadania prawa do głosowania a powszechność wyborów, "Studia Prawnicze i Administracyjne” 2017, nr 1.

Sarnecki P., Regulacje ustawowe dotyczace wyborów na terenie Rzeczypospolitej Polskiej posłów do Parlamentu Europejskiego, „Przegląd Sejmowy” 2004, nr 3.

Sarnecki P., W sprawie procedury wyborczej do Parlamentu Europejskiego, „Przegląd Sejmowy" 2003, nr 5.

Skoczylas A., Piątek W., Komentarz do art. 15 [w:] Konstytucja RP. Komentarz, t. I, Art. 1-86, red. M. Safjan, L. Bosek, Warszawa 2016.

Skrzydło W., Konstytucja Rzeczypospolitej Polskiej. Komentarz, Warszawa 2009.

Szmyt A., Normatywny wyraz idei demokracji przedstawicielskiej i bezpośredniej w Konstytucji RP z 1997 roku, „Gdańskie Studia Prawnicze” 2009, nr 1.

Szymanek J., Determinanty procesu zmiany konstytucji, „Przegląd Legislacyjny” 2015, nr 3. Szymanek J., Stosunek przedstawicielski na poziomie Unii Europejskiej (próba opisu charakteru mandatu), „Przegląd Sejmowy” 2011, nr 3.

Tuleja P., Komentarz do art. 5 [w:] Konstytucja Rzeczypospolitej Polskiej. Komentarz, red. P. Tuleja, Warszawa 2019.

Tuleja P., Stosowanie Konstytucji RP w świetle zasady jej nadrzędności, Kraków 2003.

Wojtyczek K., Przekazywanie kompetencji państwa organizacjom międzynarodowym. Wybrane zagadnienia prawnokonstytucyjne, Kraków 2007.

Wojtyczek K., Wpływ Traktatu z Lizbony na ustrój Polski, „Przegląd Sejmowy” 2010, nr 4. 